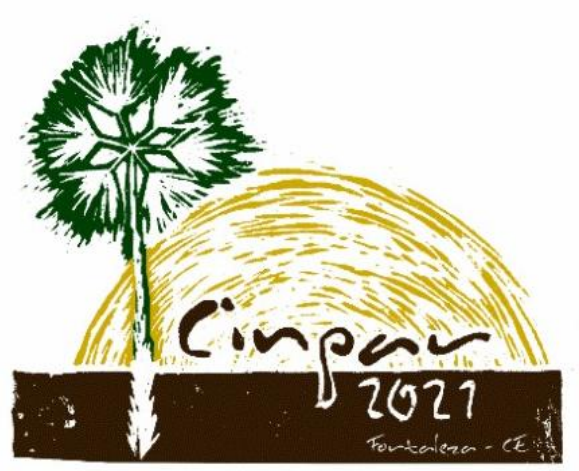

XVII Congresso Internacional sobre Patologia e Reabilitação das Construções

XVII Congreso Internacional sobre Patología y Rehabilitación de las Construcciones

XVII International Conference on Pathology and Constructions Rehabilitation

FORTALEZA (Brasil), 3 a 5 de junho de 2021

https://doi.org/10.4322/CINPAR.2021.146

\title{
Building pathologies. Analysis of three case studies
}

\author{
Michela Monaco ${ }^{1}$, Immacolata Bergamasco ${ }^{2}$, Antonino lannuzzo ${ }^{3}$, Antonio Gesualdo ${ }^{4}$, \\ ${ }^{1}$ University of Sannio, Benevento, Italy, monaco@unisannio.it \\ ${ }^{2}$ Ministry for Cultural Heritage and Activities and Tourism, Archaeological Park of Pompeii, Italy, \\ immacolata.bergamasco@beniculturali.it \\ ${ }^{3}$ ETH, Zürich, Switzerland, iannuzzo@arch.ethz.ch \\ ${ }^{4}$ University of Naples “Federico II", Napoli, Italy, gesualdo@unina.it
}

\begin{abstract}
Masonry buildings are the main part of the Architectural heritage in the World. The need of preservation for the historical memory, together with the exigence of fruition and use, has evidenced the need of appropriate analysis tools. In general, the stresses in masonry structures are usually considerably lower than those required for their material failure, so that the stability is mainly due to their shape and self weight. These aspects allowed in the past the simple realization of construction models in a reduced scale in order to assess the stability. As the history has pointed out, the behaviour of constructions is strongly linked to the workmanship and the good realization of the construction details. Local or global collapse can occur in fact due to pathologies arising during the construction or to bad realization of construction details. This paper deals with this last aspect, examining three different masonry buildings: the first one is a brick masonry building in Bologna: San Barbaziano Church, the others are two Roman domus in two different archaelogical sites in Campania: Villa Regina (Boscoreale, Napoli) and Villa dei Misteri (Pompeii, Napoli). The defects have been divided into two classes: structural defects and non structural ones. It is shown that structural defects can cause a global damage and could involve significant interventions.
\end{abstract}

Keywords: ancient masonry building; pathology.

\section{Introduction}

Knowledge and understanding the damage and failure mechanisms of masonry structures are necessary to prevent catastrophic failures and enhancing effective restoration of historical masonry monuments. The optimum approach includes historical, experimental and numerical studies to achieve a good level of knowledge. There are in fact several aspects that should be examined before developing a restoration design (De Ponti et al., 2017). In particular, experience shows that a broader study of the monument, the history and architecture of the building, its material consistence and actual state are indispensable prerequisites for the successive analyses, in order to account for all initial and consecutive construction phases, previous interventions or additions (Bosiljkov et al., 2010; Asteris, et al., 2017). Furthermore, the results of the experimental investigations regarding geometrical data, the in situ evaluation of the materials mechanical characteristics (Monaco et al., 2021a and 2021b; Guadagnuolo et al., 2020a), the properties of the structural elements like masonry walls, arches, vaults and floors, the complex response of the construction to different possible actions, as well as the results of eventual previous monitoring can be crucial for reliable designing interventions on ancient structures (Monaco et al., 2014; Gesualdo and Monaco, 2015; Guadagnuolo et al., 2020b, 2020c). In the case of San Gimignano towers “...the construction is surprising, the method is based on very thick stone masonries and extraordinary mortars, with just a few 
later exceptions where bricks were used" (Giorgi and Matracchi, 2017). Sometimes the structural conception of the building or an unsuitable realization of retrofit interventions (Krentowski et al., 2017) is the major cause of collapse. The simple knowledge of the material properties and the actual geometry of the structure cannot be in fact sufficient if not appropriately connected to a rational coordination of the information about the whole past of the monument (Frunzio et al., 2019). As the history has pointed out, the behaviour of constructions is strongly linked to the workmanship and the good realization of the construction details. Differently from the cases in which the strength of the masonry wall is directly involved, like in the in-plane failure (Gesualdo et al, 2019 and 2020; Monaco et al., 2018b), local or global collapse can occur in fact due to pathologies arising during the construction or to bad realization of construction details (Buonocore et al., 2014; Gesualdo et al., 2020). This paper deals with this last aspect, examining three different masonry buildings: the first one is a brick masonry building in Bologna: San Barbaziano Church, the others are two Roman domus in two different archaelogical sites in Campania: Villa Regina, Boscoreale, Napoli and Villa dei Misteri, Pompeii, Napoli.

\section{Structural construction pathologies: the San Barbaziano Church in Bologna}

The unconsecrated San Barbaziano Church (Figure 1.a) is a brick masonry building the corner of Via Barberia and Via Cesare Battisti in Bologna. It was built between 1608 and 1612 by Pietro Fiorini in place of the previous late Middle Age Monastery Church, become inappropriate according the new religious statements of the Trento Council. The Church is formed by a late Mannerist single nave with eight side chapels belonging to the original Church, separated by masonry piers and incorporated in the new building at the ground level (Figure 1.b).

The higher part of the Church consists of the central nave only (45 length, $11 \mathrm{~m}$ wide), with external masonry buttresses corresponding to the separation walls of the lower chapels. The walls are very slender, considering the $85 \mathrm{~cm}$ thickness of both façade, apsis walls and lateral walls of the ground level chapels. The longitudinal walls present $40 \mathrm{~cm}$ thickness at both the levels. The three-bay nave is longitudinally counterpointed by two barrel vaults with lunettes and a central bay with a cloister vault. A second cloister vault covers the apsis.

a

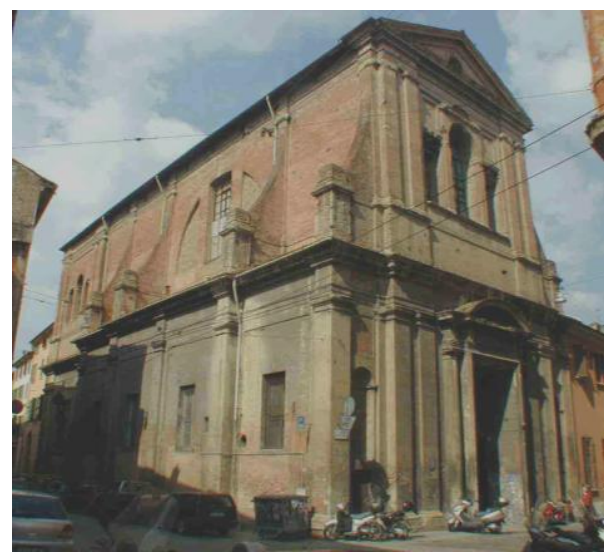

b

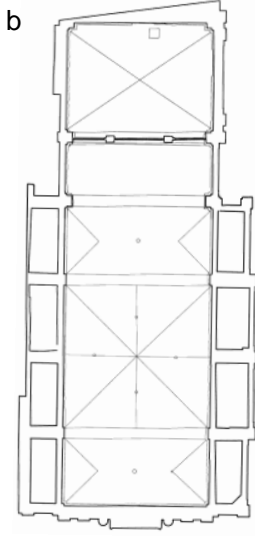

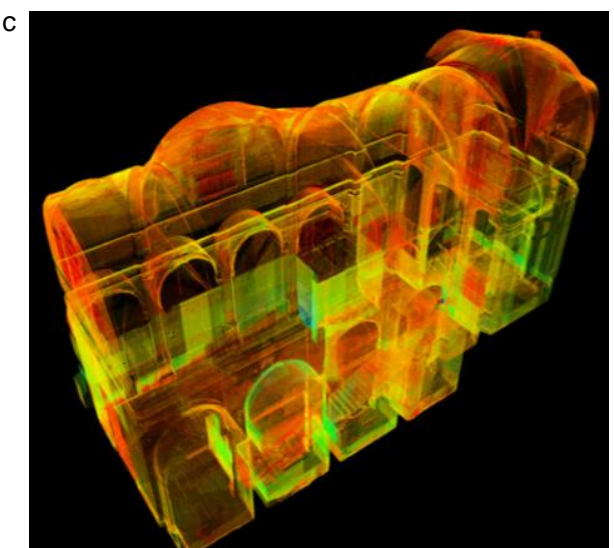

Figure 1. (a) San Barbaziano Church; plan of the building (b); (c) Laser-scanner survey of the Church.

Eleven timber trusses provide support for the roof tiles. At the end of XVIII century the building was dismissed as Church and used as deposit, until the actual property, the Ministry for Cultural Heritage, Activities and Tourism has decided to plan retrofit interventions to change the use of the building. A complete diagnosis plan has been developed and realized to develop a restoration design for the reuse of the building (Bergamasco and Poggioli, 2012), including a laser-scanner survey (Figure 1.c). The considerations below a take in account only a part of the large survey conducted on the Church, in order to highlight the characteristics of the structural system that are cause of the detected damage (Monaco et al., 2018a). The complete map cracking has been simplified putting in evidence only the damage that can be referred to a specific construction issue. In Figure 2. a diagonal crack on the longitudinal wall is 
representative of the overturning of the facade (Gesualdo et al., 2017; Guadagnuolo and Monaco, 2009). The crack is present only on the side wall along Via Barberia, while in the wall over the adjoining cloister minor cracks have been detected. The corner position of the building shown in Figure 2.b together with the limited stiffness of the longitudinal walls seem to be the main cause of the damage. By a careful reading of the monument history it is deduced that the Municipality allowed "the construction of the façade outside the ancient church in the public land for ounces $18(57 \mathrm{~cm})$ ", so that a crack due to settlement is compatible with the construction history (lannuzzo et al., 2018).

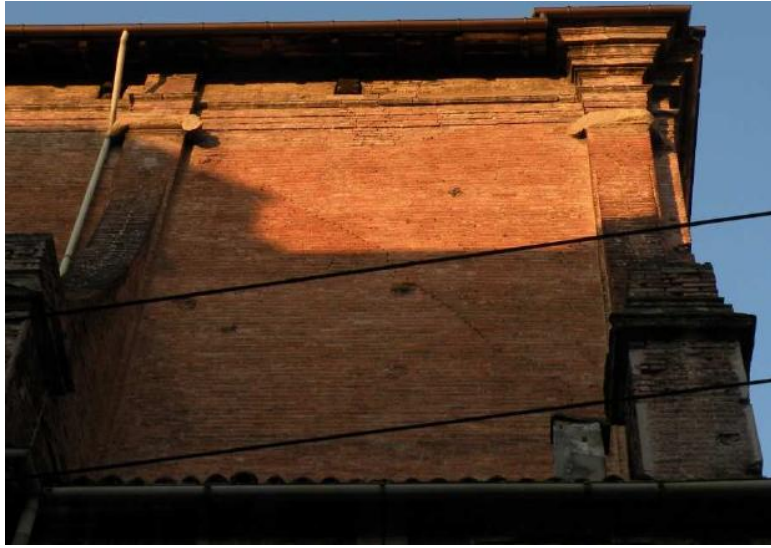

b

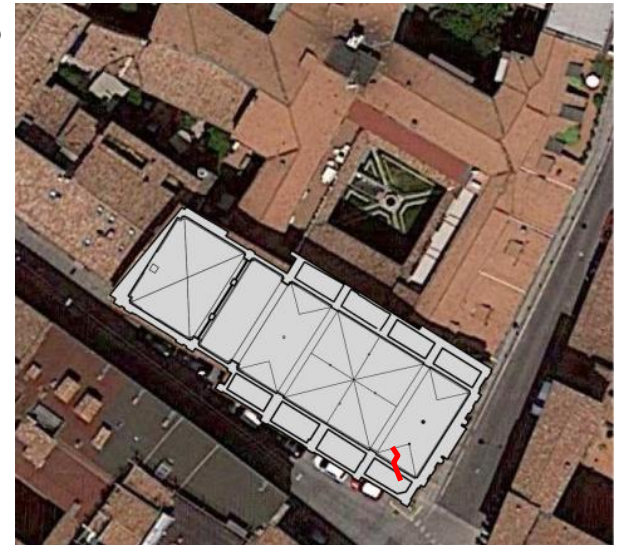

Figure 2. (a) Diagonal crack in the masonry wall at the second level; (b) Position of the Church and its surroundings.

In Figure 3.a the longitudinal crack present at the upper level of the church is highlighted. The crack is undoubtedly due to the extremely vulnerable roofing system.

a

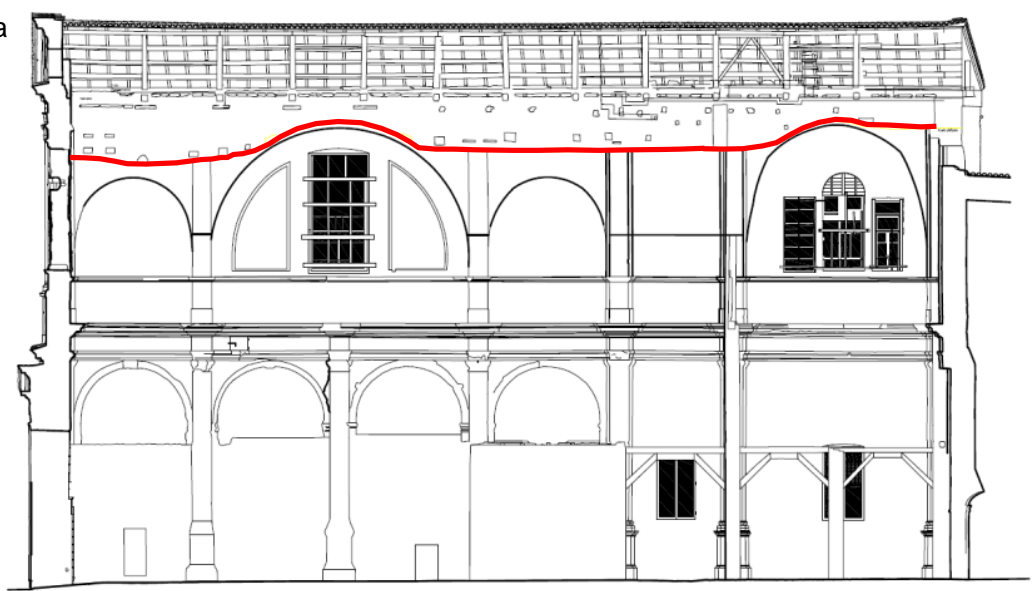

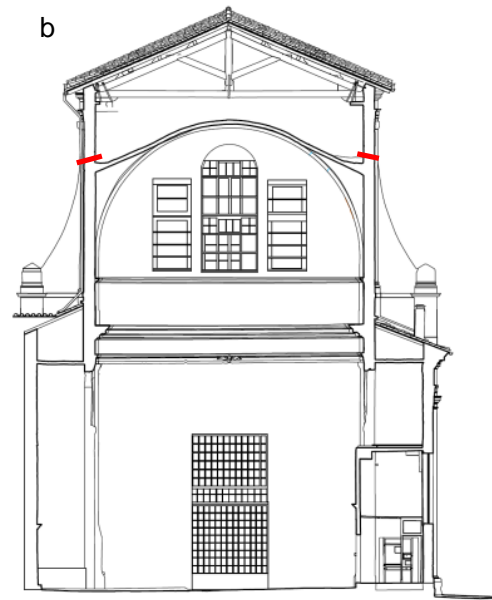

Figure 3. (a) Longitudinal section of San Barbaziano Church; (b) Transversal section of the Church.

As it can be noted in Figure 3.b, the buttresses placed at the second level end the intersection with the vaults extrados, so that the remaining roofing structure is composed by the slender perimetral walls and the timber trusses. The two longitudinal masonry walls form with the timber elements an extremely vulnerable system, especially for out-of -plane actions, as the longitudinal crack in Figure 3.a testifies (Gesualdo and Monaco, 2010). The nave mechanism is represented in Figure 4, together with the involved structural scheme.

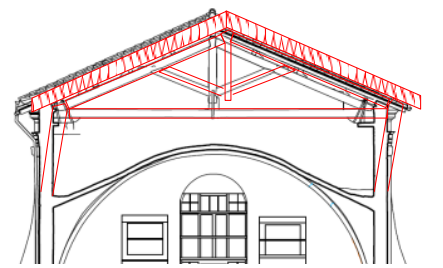

a

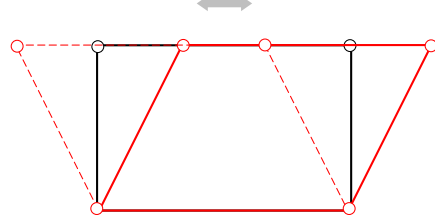

b

Figure 4. (a) Possible nave mechanism; (b) structural scheme. 


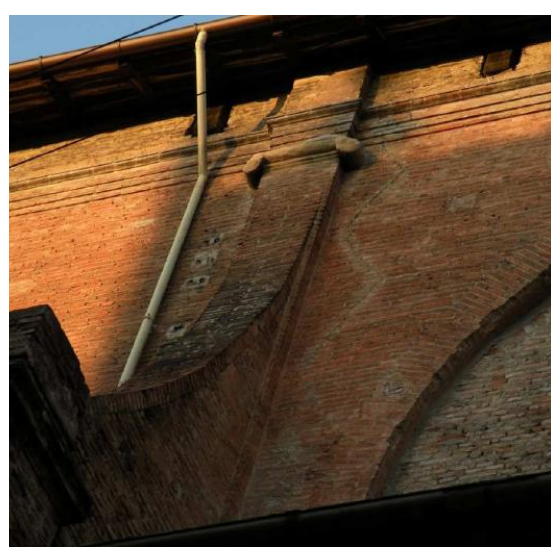

C

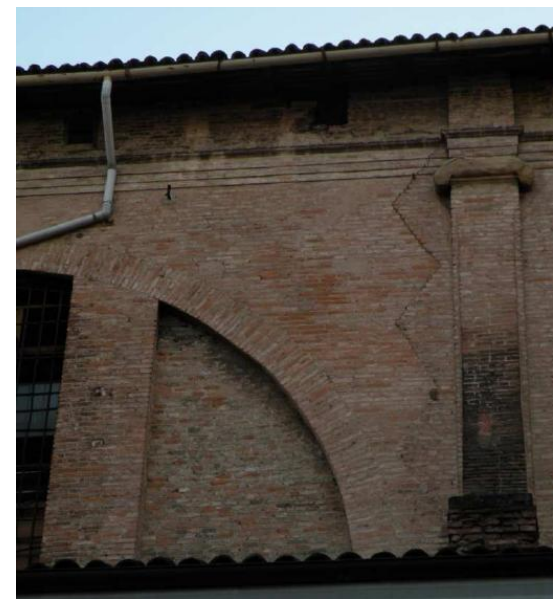

b 輬

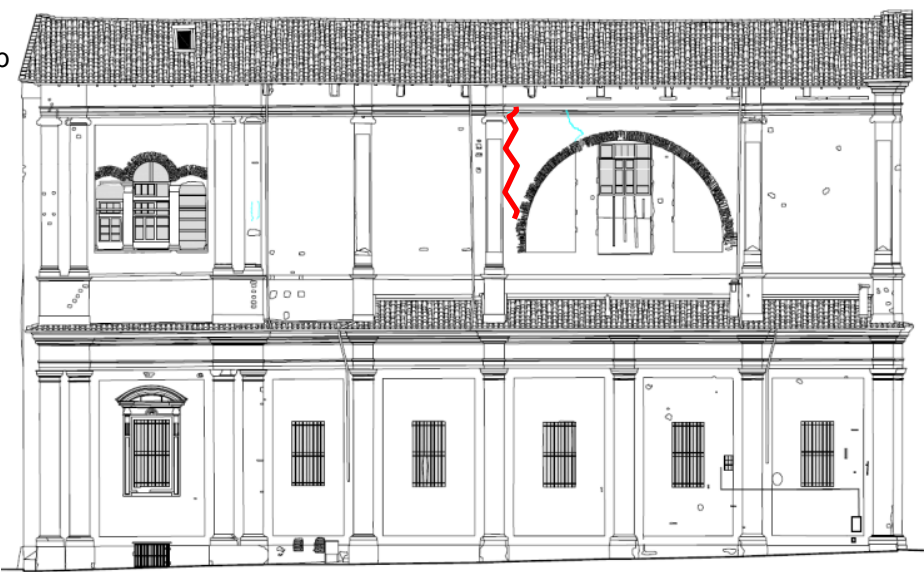

d

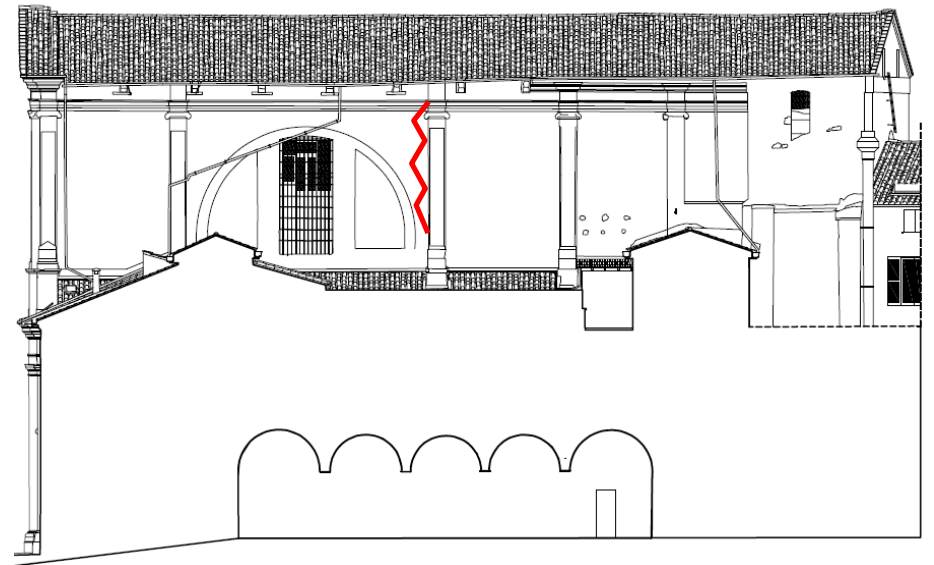

Figure 5. $(a, c)$ Bad masonry toothing; (b, d) Position of the toothing.

Figure 5 reports the detail of two masonry bonding realized during the construction at the same level and in the same longitudinal position in the Church. The incorrect toothing produces as a result a defect in the masonry wall continuity.

\section{Pathologies due to details realization: timber roofs}

Timber and masonry structures have been the first ones employed in constructions, in fact the realization of timber structures has been in the past the only solution to support roof tiles. Knowledge of the ancient timber structures involves structural, historical, technological and biological aspects. Building materials are decayed by the effects of adverse environmental conditions and the extent of damage depends on both the materials and the environmental conditions (De Matteis et al., 2019).

Differently from inorganic materials like stones and mortars, this is strongly true for timber, where undesirable change in the properties of the material are brought about by the activities of living organisms (Faggiano et al., 2013). The eleven braced king-post timber trusses of San Barbaziano have been realized with two different timber species same age (Picea abies and Abies alba) that present similar mechanical characteristics, partly with rectangular (Figure 6.a) and partly with almost round cross section (Figure 6.b).

Fortunately, the timber principal structure is in good state of conservation, due to the good realization of the truss end supports, allowing a good ventilation of the structure. 
a

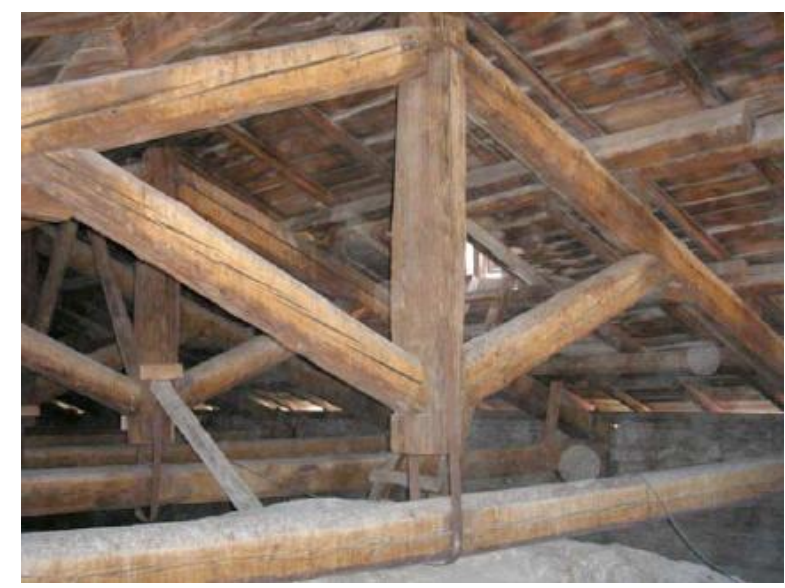

b

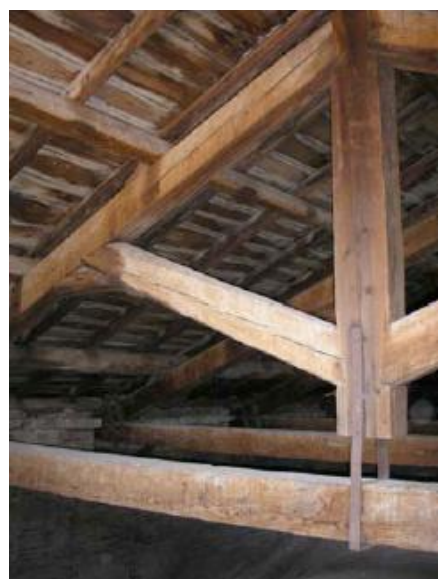

Figure 6. (a) Circular cross sections; (b) rectangular cross sections.

The trusses are placed on a timber cantilever (80-100 cm length), isolated from the masonry load bearing wall (Figure 7.a, b). The truss ends are covered by the roof eaves and free air movement are allowed around timber, so that the presence of fungine attacks is mainly due to poor maintenance of the roof. The principal damage regards the post-rafters connections, as reported in Figure 7.b. Due to the negligent care in fact the purlins and the timber plates shall be substituted (Bergamasco et al., 2009).

a

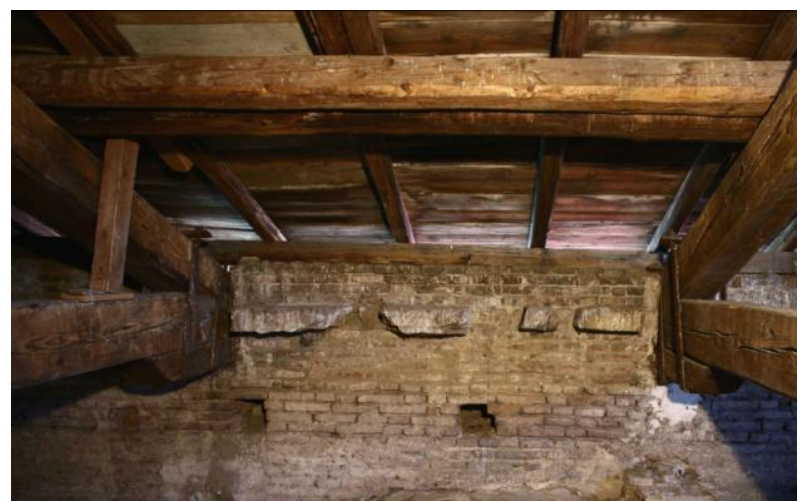

b

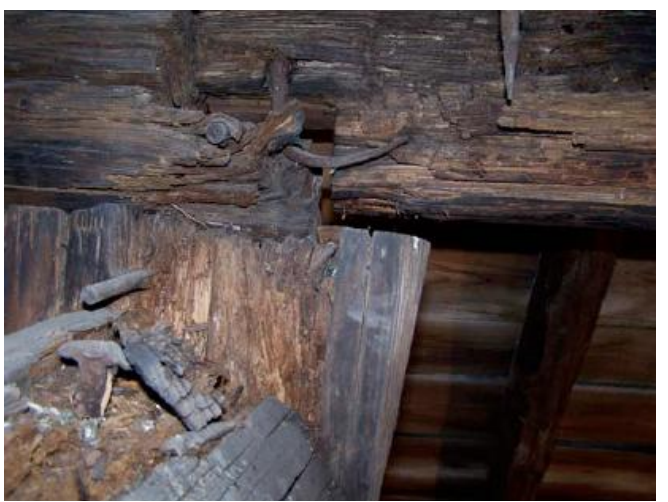

Figure 7. (a) Truss end supports; (b) Post-rafters connection

A different case is that of Pompeian roofs. A large part of them has been realized after the Pompeii discovery, so that the presented exempla regard restoration interventions (Bergamasco et al., 2018). Differently from San Barbaziano trusses, the Pompeii roofs have a long history of bad realization of construction details, poor maintenance and in some cases collapses.

This last case is that of Villa dei Misteri peristilium roof, in which a rafter collapsed on 8th September 2012. In this case the main cause of the damage is due to bad realization of the rafter end support. Like in several Pompeian Domus, the timber rafters have not been isolated from damp masonry by air space or damp proof membrane, so to allow free air movement, but are directly placed in the masonry wall. Figure 8.a shows the peristilium rafter before the collapse, while in Figure 8.b the rafter end support after the collapse is reported. A neighbour rafter is reported in Figure 8.c.

As it can be seen, the end support conditions are similar to those of the collapsed one. Recently the Pompeii Archeological Park has carried out an in-situ experimental campaign to assess the conservation state of the roofing structures of Villa dei Misteri in order to develop a restoration intervention on the Villa (Bergamasco et al., 2017). 

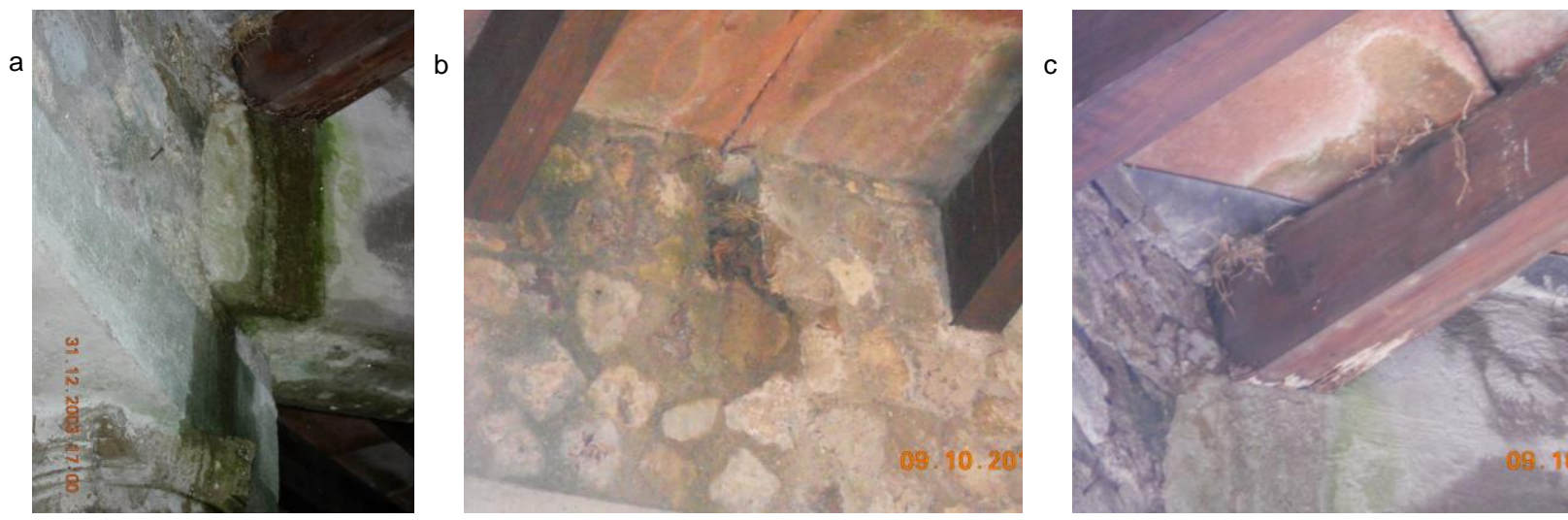

Figure 8. (a) Rafter end support before collapse; (b) End support after collapse; (c) Actual end support conditions of the remaining rafters

The first restoration intervention on the roofing structure of Villa Regina, the only Rural Villa in the Vesuvian area open to the public, significant part of the archaelogical area of Boscoreale, can be an efficient example of incorrect construction detail. The timber roof placed on the Southern rooms of Villa Regina (indicated with a red arrow in Figure 9.a) was designed for archaeological reasons with a limited slope, since in the case of Villa Regina the original roofing structures have been excavated at the end of 1979 (Figure 9.b) and could be surveyed (Bergamasco et al., 2016; Monaco et al., 2020).
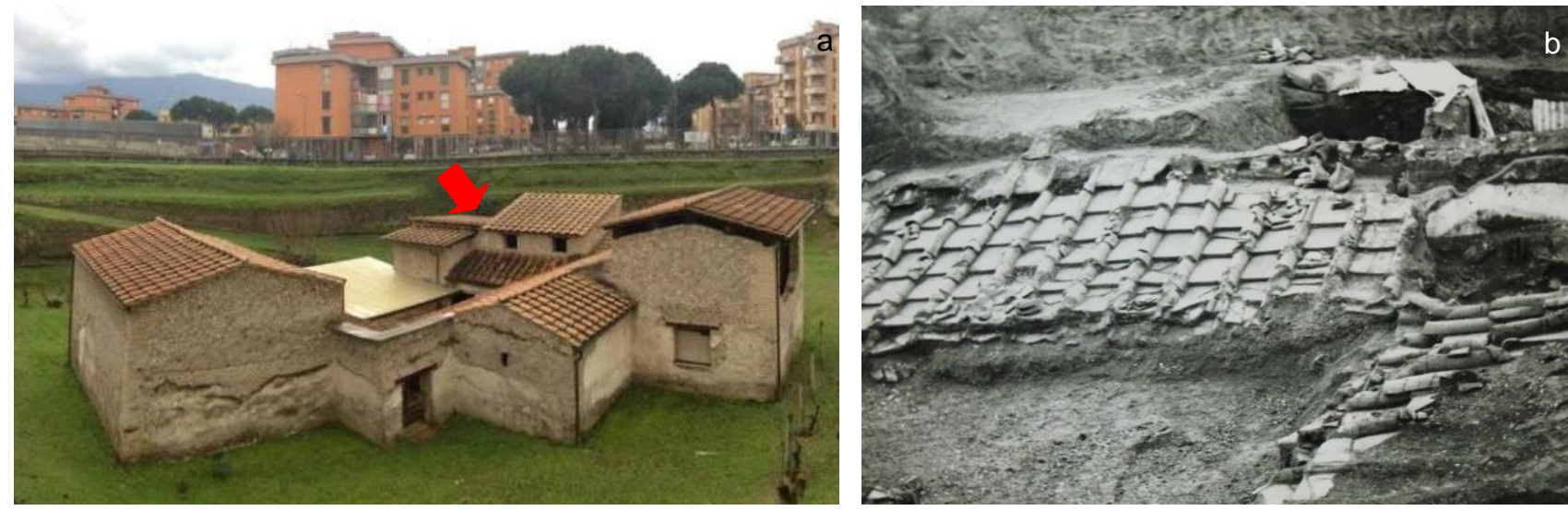

Figure 9. (a) General north view of the Villa; (b) The excavation of Villa Regina: detail of the original porticus roofing.
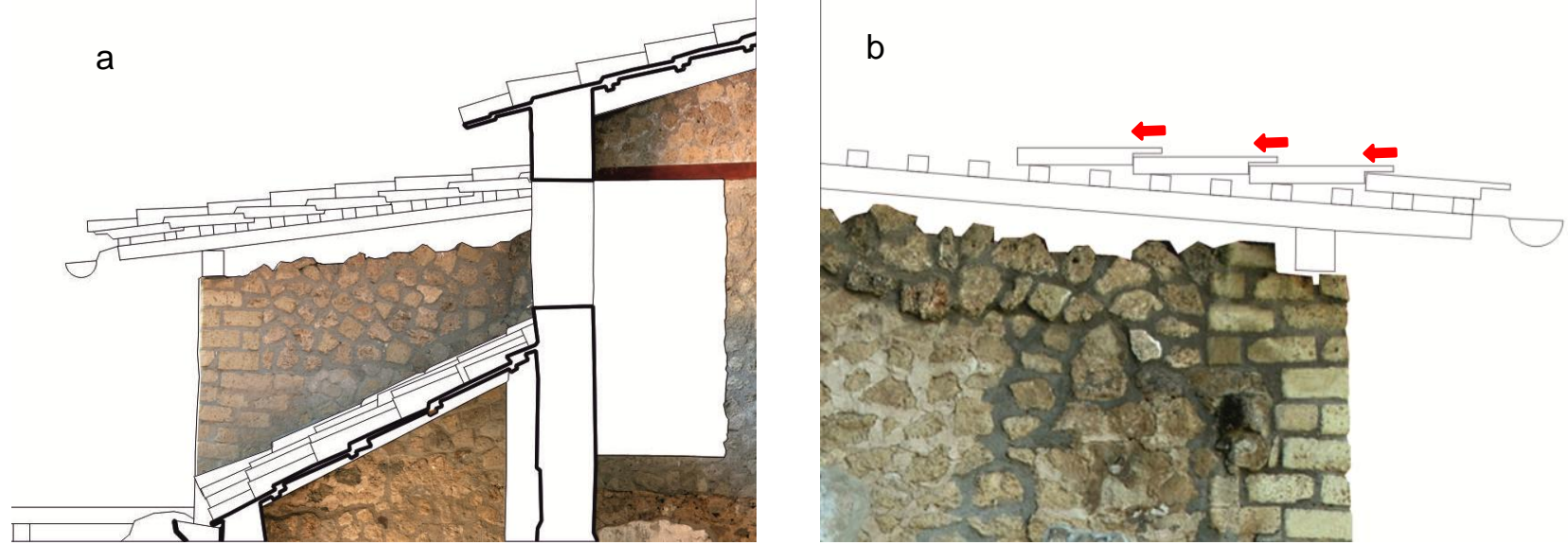

Figure 10. (a, b) Sections of Villa Regina roofing structures 

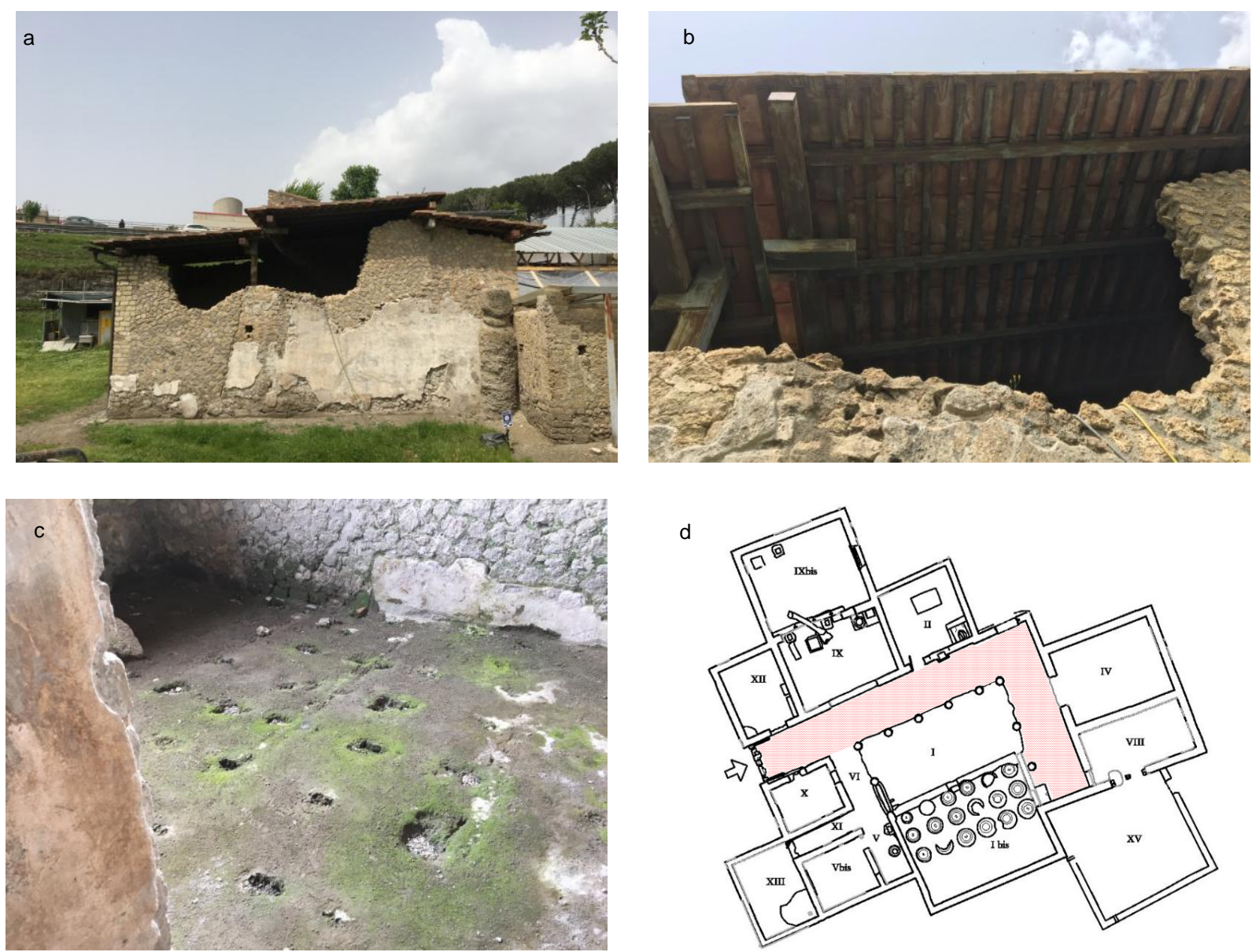

Figure 11. (a) North view of Villa Regina; (b) Detail of the roof; (c) Effects of leaching by rainwater; (d) plan of the villa

Unfortunately, the manufacturing of tiles and their definitive placing was not considered in the first restoration design, so that the rainwater flow turns backward, creating damage to the structures below (Bergamasco et al., 2017). Actually, the restoration works, that include the substitution of the roofing structures, are ongoing (Bergamasco, 2015).

The pictures presented do not need comments, since the effects of the incorrect design and realization are clearly visible in Figure 11.c, where the pavement surface runoff and erosion are reported.

\section{Conclusions}

This paper presents a discussion on the influence of construction details (structural or technological) on the pathology present in a building. It has been shown that the only maintenance is sufficient in buildings where the construction details are well designed and realized. On the other side, bad structural conception or realization cannot be overcome with a simple maintenance intervention, but a more complex system of interventions is needed to enhance the building conception. Three case studies, San Barbaziano Church (Bologna), Villa Regina (Boscoreale, Napoli) and Villa dei Misteri (Pompeii, Napoli) have been presented to give evidence of the problem. It is shown that structural defects involve damages on the global structure of the building, with consequent significant and expensive interventions, while technological defects can be the cause of local damages, to be repaired with limited interventions.

\section{Acknowledgments}

The authors acknowledge the Ministry for Cultural Heritage and Activities and Tourism, Archaeological Park of Pompeii and Superintendency of Bologna, Modena, Reggio Emilia, for the permission of taking 
measurements and using images respectively of the Pompeii site and the San Barbaziano Church, all rights reserved.

\section{References}

Asteris, P. G., Douvika, M. G., Apostolopoulou, M., Moropoulou, A., 2017. Seismic and Restoration Assessment of Monumental Masonry Structures. Materials, 10(8), 895.

Bergamasco, I., 2015. Progetto coperture di Villa Regina, Rivista di studi pompeiani, XXVI.

Bergamasco, I., Bernabei, M., Macchioni, N., 2009. L'inquadramento storico di strutture in legno: I'esempio della copertura della chiesa di San Barbaziano a Bologna. In: Conservare e restaurare il legno; conoscenze, esperienze e prospettive, 205-216, Edizioni Arcadia Ricerche, Marghera-Venezia (In Italian).

Bergamasco, I., Fortunato, A., Gesualdo, A., lannuzzo, A., Monaco, M., 2017. A no-tension model for the analysis of combined masonry vaults, Atti del XXIII Congresso dell'Associazione Italiana di Meccanica Teorica ed Applicata, Salerno, Italy, September 4-7.

Bergamasco, I., Gesualdo, A., Guerriero, A., lannuzzo, A., Monaco, M. 2016. Roofing interventions in the Pompeii Tragic Poet House, Proc. XIV International Forum "Le vie dei mercanti", Napoli - Capri, Italy, La Scuola di Pitagora Editrice, Naples.

Bergamasco, I., Gesualdo, A., lannuzzo, A., Monaco, M., 2018. An integrated approach to the conservation of the roofing structures in the Pompeian domus, Journal of Cultural Heritage, 31, 141-151.

Bergamasco, I., Marzo, A., Marghella, G., Carpani, B., 2017. In-situ experimental campaign on the covering structures of "Villa dei Misteri" in Pompeii. Journal of Civil Structural Health Monitoring, 1-17.

Bergamasco, I., Poggioli, C., 2012. Rapporto conclusivo della campagna diagnostica svolta a cura della Direzione Regionale per i Beni Culturali e Paesaggistici dell'Emilia Romagna riguardante le indagini propedeutiche al progetto di restauro della Ex Chiesa di San Barbaziano, MiBACT (in Italian).

Bosiljkov, V., Uranjek, M., Žarnić, R., Bokan-Bosiljkov, V., 2010. An integrated diagnostic approach for the assessment of historic masonry structures. Journal of Cultural Heritage, 11(3), 239-249.

Buonocore, G., Gesualdo, A., Monaco, M., Savino, M.T. (2014) Improvement of Seismic Performance of Unreinforced Masonry Buildings using Steel Frames, in: Civil-Comp Proceedings: 106, B.H.V. Topping and P. Iványi eds., Civil Comp Press, Kippen, Stirlingshire, U.K., ISBN 978-1-905088-61-4, doi: 10.4203/ccp.106.117

De Matteis G., Corlito V., Guadagnuolo M. and Tafuro A. (2019). "Seismic Vulnerability Assessment and Retrofitting Strategies of Italian Masonry Churches of the Alife-Caiazzo Diocese in Caserta, Int. J. Architectural Heritage, 14(8), 1180-1195.

De Ponti, R. D., Cantini, L., Bolondi, L., 2017. Evaluation of the masonry and timber structures of San Francisco Church in Santiago de Cuba through nondestructive diagnostic methods. Structural Control and Health Monitoring, 24(11), 1-17.

Faggiano, B., Grippa, M. R., Calderoni, B., 2013. Non-destructive tests and bending tests on chestnut structural timber. Advanced Materials Research, 778, 167-174.

Frunzio, G., Di Gennaro, L., Guadagnuolo, M., 2019. Palazzo Ducale in Parete: remarks on code provisions, Int. J. Masonry Research and Innovation, 4(1-2).

Gesualdo, A., Calderoni, B., lannuzzo, A., Fortunato, A., Monaco, M. 2020. Minimum energy strategies for the in-plane behaviour of masonry, Frattura ed Integrità Strutturale, 14(51), 376-385.

Gesualdo, A., Calderoni, B., Sandoli, A., Monaco, M. 2019. Minimum energy approach for the in-plane shear resistance of masonry panels, Ingegneria Sismica, 36(1), 42-53.

Gesualdo, A., lannuzzo, A., Monaco, M., Penta, F., 2017. Rocking of a rigid block freestanding on a flat pedestal, Journal of Zhejiang University-SCIENCE A, doi: 10.1631/jzus.A1700061 
Gesualdo, A., Monaco, M., 2010. Seismic vulnerability reduction of existing masonry buildings. Modelling of retrofitting techniques. In: Urban Habitat Construction Under Catastrophic Events, 1, 853-858, London, New York: CRC Press, Taylor \& Francis Group.

Gesualdo, A., Monaco, M., 2015. Constitutive behaviour of quasi-brittle materials with anisotropic friction, Latin American Journal of Solids and Structures, 12(4), 695-710.

Giorgi, L., Matracchi, P., 2017. Architectural Evolution: Modifications, Alterations, and Restorations through Centuries. Journal of Performance of Constructed Facilities, 31(5), 04017046.

Guadagnuolo, M., Monaco, M. 2009. Out of plane behaviour of unreinforced masonry walls. In: Protection of Historical Buildings, 2, 1177-1180, London, New York: CRC Press

Guadagnuolo, M.; Aurilio, M.; Basile, A.; Faella, G. 2020a. Modulus of Elasticity and Compressive Strength of Tuff Masonry: Results of a Wide Set of Flat-Jack Tests. Buildings, 10, 84.

Guadagnuolo, M.; Aurilio, M.; Faella, G., 2020b. Retrofit assessment of masonry buildings through simplified structural analysis, Fracture and Structural Integrity, 14, 398-409.

Guadagnuolo, M.; Faella, G., 2020c. Simplified Design of Masonry Ring-Beams Reinforced by Flax Fibers for Existing Buildings Retrofitting. Buildings 2020, 10, 12.

Iannuzzo, A., Angelillo, M., De Chiara, E., De Guglielmo, F., De Serio, F., Ribera, F., Gesualdo, A., 2018. Modelling the cracks produced by settlements in masonry structures. Meccanica, 53(7), 1857-1873.

Krentowski, J., Chyzy, T., Dunaj, P., 2017. Sudden collapse of a 19th-century masonry structure during its renovation process. Engineering Failure Analysis, 82, 540-553.

Monaco M, Aurilio M, Tafuro A, Guadagnuolo M., 2021a. Sustainable Mortars for Application in the Cultural Heritage Field, Materials, 14(3), 598.

Monaco, M., Bergamasco, I, Betti, M. 2018. A no-tension analysis for a brick masonry vault with lunette, Journal of Mechanics of Materials and Structures, 13(5), 703-714.

Monaco, M., Calderoni, B., lannuzzo, A., Gesualdo, A., 2018. Behaviour of in-plane loaded masonry panels, Procedia Structural Integrity, 11, 388-393.

Monaco M., Faella G., Guadagnuolo M., 2021b. Analysis of pozzolanic mortars for restoration, International Journal of Conservation Science, 12(1), 41-50.

Monaco, M., Guadagnuolo, M., Gesualdo, A., 2014. The role of friction in the seismic risk mitigation of freestanding art objects. Natural Hazards, 73(2), 389-402.

Monaco, M., Iannuzzo, A., Tafuro, A., Gesualdo, A.,2020. Dynamic analysis of a Pompeian domus, Proc. EURODYN2020, EASD International Conference on Structural Dynamic, 2, 4922-4929. 